Бұл CC BY-NC-ND лицензиясы бойынша қол жетімді мақала (https://creativecommons.org/licenses/by-nc-nd/3.0/) «Ғылымның өзекті мәселелері» - Халықаралық практикалық интернет- конференция материалдары

Басылым II, Қараша 2019

ISBN 978-601-323-144-0

https://doi.org/10.31643/2019.025

Отаров Ертай Жалгасбаевич,

медицина ғылымдарының докторы, ҚР

ЕжәнеХӘҚМ Еңбекті қорғау жөніндегі республикалық ғылыми-зерттеу институтының

ШЖҚ РММ Қарағанды облыстық филиалы,

Қарағанды қаласы, Қазақстан Республикасы

E-mail: otarov_kgmu@mail.ru,

ORCID ID: 0000-0001-5799-3451
Мусаханова Маншук Сериковна, техника ғылымдарының магистрі, «Kazakhmys Maker «(Қазақмыс Мэйкер)» ЖШС, Қарағанды қаласы, Қазақстан Республикасы,

E-Mail: Manshuk.Musahanova@kazakhmys.kz ORCID ID: 0000-0002-6370-8247

\title{
Мердігерлік ұйымдар жұмыскерлерінің еңбек қауіпсіздігі мен енбектерін қорғау мәселелері және оларды шешу бойынша ұсыныстар
}

\begin{abstract}
Абстракт: Мақалада ірі өндірістік кәсіпорындарының аумағынде жұмыс істейтін мердігерлік ұйымдар қызметкерлерінің қауіпсіздігі мен жазатайым оқиғалардың алдын алу шаралары келтірілген. Қазіргі таңда көптеген ірі компаниялар жұмыстарды өндіру үшін мердігер ұйымдарды жалдайды, сондықтан соңғы жылдары қалыптасқан мердігерлік ұйымдар қызметкерлерінің жоғары жарақаттану жағдайы көптеген жұмыс берушілердің осы қызметкерлердің қауіпсіздігін арттыру мәселесіне қызығушылығын қайта жандандырды. Мердігер компаниялардың жұмыскерлері көп жағдайда тапсырыс берушінің аймағында жарақатталады, ал жазатайым оқиғалардың негізгі себебі ретінде жұмыс жүргізудің қанағаттанғысыз ұйымдастырылуы болып табылады. Мердігерлік жұмыстарды пайдалану кеңінен таралғанына қарамастан, осы уақытқа дейін осы мәселені шешу тәсілдеріне бірыңғай көзқарас қалыптаспаған. Жазатайым оқиғаны тергеп-тексеру актісінде және жазатайым оқиға туралы актісінде үшінші жақтардың кінәсін көрсету мүкіндігі пайда болған жағдайда жұмыскері зардап шеккен кәсіпорын үшін жағымсыз салдардың азаюы анық.
\end{abstract}

Түйін сөздер: еңбекті қорғау, қауіпсіздік, жарқаттану, жазатайым оқиғалар, мердігерлік ұйымдар.

Кейбір компаниялар қауіпсіздікті жақсарту мүмкіндігін негізінен мердігерлік ұйымдарды жұмысқа жіберу процесін регламенттеумен байланыстырады. Басқалары - қауіпсіздік резервтерін техникалық бақылау құралдары мен айыппұл санкцияларын қолдануды қоса алғанда, мердігерлік ұйымдар қызметкерлерінің жұмысын қадағалау мен бақылауды ұйымдастыруда көреді. Мәселенің әмбебап шешілімінің болмауы оның күрделілігі мен көпаспектілігін айғақтайды [1].

Мердігерлік жұмыстарға қатысты OHSAS 18001:2007 стандартында талаптар қамтылған, оларға сәйкес ұйым мердігерлерге және жұмыстарды орындау аймағының басқа да келушілеріне байланысы бар басқару құралдары мен әдістерін енгізіп, оларды өзекті күйде ұстауға тиіс [2].

Бұл құралдар келесі жалпы шараларды қамтуы тиіс:

- мердігерлерді таңдау критерийлерін анықтау;

- мердігерлерде қойылатын ұйымдағы еңбекті қорғау бойынша талаптарды хабарлау;

- мердігерлердің сипаттамаларын бағалау, мониторинг және мерзімді қайта бағалау, сондайақ, бақылау шаралары; 
- кіріс бақылауы;

- жабдықтарды пайдалануға рұқсат беру алдында білім мен мінез-құлық сипатын анықтау;

- қажет болған жағдайда оқыту мен ұсыныстарды ұсыну;

- техникалық құралдар (ескертетін электрондық табло және маңдайша);

- әкімшілік бақылау;

- кәсіпорын аумағында келушілердің жүріп-тұруына мониторинг ұйымдастыру және олардың жұмысын басқару.

Тапсырыс беруші мен мердігер ұйым арасында дер кезінде ақпарат алмасу мүмкіндігі үшін жұмыс беруші жұмыстарды орындау аймағының мердігерлермен және басқа да келушілермен тиісті коммуникация рәсімдерін әзірлеп, қолдауы тиіс. Келтірілген OHSAS 18001:2007 стандарт талаптарын XEҰ-ILO-OSH 2001 Басшылығының нұсқауларымен толықтыру қажет. Атап айтқанда, ұйым алаңында жұмыс істейтін мердігерлерге қажет іс-шаралар төмендегі жағдайларды қамтуы тиіс:

- мердігерлерді бағалау және таңдау рәсімдеріне еңбекті қорғау өлшемдерін енгізу;

- ұйым мен мердігерлердің тиісті басқару деңгейлері арасындағы тиімді ағымдағы байланыс пен үйлестіруді жұмыс басталғанға дейін белгілеу (бұл ретте қауіптер туралы хабардар ету үшін жағдайларды және олардың әсерінің алдын алу және оларды шектеу жөніндегі шараларды қамтамасыз ету қажет).

- ұйым үшін жұмыстарды орындау кезінде мердігер қызметкерлерінің жарақаттануы, денсаулығының нашарлауы, аурулары және оқыс оқиғалар туралы хабарлама жөніндегі іс-шараларды енгізу;

- қауіпсіздік пен денсаулық сақтауды қамтамасыз ету үшін жұмыс орындарының қауіптерімен тиісті танысуды және қажеттілігіне қарай мердігерлер немесе олардың қызметкерлері үшін жұмысты бастамас бұрын немесе жұмыс барысында дайындықты қамтамасыз етуге міндетті;

- ұйым алаңындағы мердігердің қызметінде еңбекті қорғау талаптарының сақталуын әдістемелік қадағалау;

- ұйым алаңындағы еңбекті қорғау бойынша, талап етілетін шаралар және процедуралар мердігерлермен орындалуы тиіс [3].

Мердігер компаниялардың жұмыскерлері көп жағдайда тапсырыс берушінің аймағында жарақатталады, ал жазатайым оқиғалардың негізгі себебі ретінде жұмыс жүргізудің қанағаттанғысыз ұйымдастырылуы болып табылады. Бұл себеп бірнеше жағдайлармен байланысты болады, атап айқанда:

- инженерлік-техникалық жұмыскерлер тарапынан бақылаудың әлсізденуі немесе жоқ болуы;

- инженерлік-техникалық жұмыскерлердің орындаушы тәртіптерінің төмен жағдайы;

- тәуекелдерге бағалауды және қатерлерді айқындауды жүргізбеу;

- тапсырыс беруші тарапы жағынан жасырын тәуекелдер туралы ескертпеу;

- тапсырыс берушімен және басқа мердігер ұйымдармен жұмыстардың келістірілмеуі;

- наряд-рұқсатта және жұмыстарды ұйымдастыру жобасында көрсетілген ұйымдастырушылық-техникалық шараларды орындамау;

- жұмысқа жіберер алдында қауіптерді идентификациялауды және тәуекелді бағалауды толық жүргізбеу.

Мердігер ұйымдардың жұмыскерлерімен болған жазатайым оқиғалар тапсырыс берушінің немесе басқа мердігер ұйымның кінәсінен болды деп анықталса, келесі қиындықтар туындайды.

Қазақстан Республикасы Денсаулық сақтау және әлеуметтік даму министрінің 2015 жылғы 28 желтоқсандағы № 1055 бұйрығымен бекітіліген еңбек қызметіне байланысты жазатайым оқиғаларды тергеп-тексеру материалдарын ресімдеу бойынша нысандарға сәйкес жазатайым оқиға туралы актісінде жазатайым оқиғаны тергеп-тексерген комиссиямен анықталған зардап шеккен жұмыскер мен жұмыс берушінің кінә дәрежелері пайыздық мөлшерде көрсетіледі, үшінші жақтардың (зардап шеккен жұмыскер еңбек қатынастарында болмаған) кінәсі көрсетілмейді. Алайда, практика көрсеткендей, көп жағдайда өндірісте жазатайым оқиғалардың себептері ретінде осы үшінші жақтардың кінәсі болып табылады.

Кейіннен жазатайым оқиғалар салдарын өтеу (зардап шеккен жұмыскердің еңбекке жарамсыз парақтарын төлеу, оның емделуіне және қалпына келуіне жұмсалатын қаражаттарды төлеу, регресстік төлемдер (зардап шеккен жұмыскер мүгедек болып қалса) жұмыс берушіге жүктеледі. Нақты кінәлі жақтан аталған шығындарды өндіріп алу ұзақ мерзімге созылып, көп жағдайда сот арқылы жүзеге асырылады.

Сонымен, жазатайым оқиғаны тергеп-тексеру актісінде және жазатайым оқиға туралы актісінде үшінші жақтардың кінәсін көрсету мүмкіндігінің жоқтығы келесі салдарға әкеліп соғады: 
- жұмыскері зардап шеккен ұйымның бейнесінің (имиджінің) және беделінің нашарлауы;

- ұйымның өндірістік жарақаттану статистикасының нашарлауы және жұмыс беруші қызметін декларациялау және сенім сертификатын алу мүмкіндігінің жойылуы; төмендеуі;

- нашар өндірістік жарақаттану статистика салдарынан кәсіпорын бәсекеге жарамдылығының

- кінәлі үшінші жақтан шығындарды өндіріп алудың ұзақ мерзімге созылуы [4].

Қорытындылай айтқанда, жазатайым оқиғаны тергеп-тексеру актісінде және жазатайым оқиға туралы актісінде үшінші жақтардың кінәсін көрсету мүкіндігі пайда болған жағдайда жұмыскері зардап шеккен кәсіпорын үшін жағымсыз салдардың азаюы анық.

Ал тапсырыс берушімен және басқа мердігер ұйымдармен жұмыстардың келістірілмеуінен орын алған жазатайым оқиғалардың мән-жайы мен себептерін талдап, жөндеу жұмыстарын жүргізу кезіндегі пайда болатын тәуекелдерді ескере отырып, келесі шаралар ұсынылады:

1) Наряд-рұқсатты алар кезінде жұмыстарды өндіруші:

- наряд-рұқсатты берушіден оны толтырған кезде нақты іс-әрекеттерді көрсетумен орындалатын жұмыстың толық атауын, жұмыстардың қауіпсіздігін қамтамасыз ету бойынша нақты іс-шаралардың көрсетілуін талап етуге міндетті;

- жұмыстарды ұйымдастыру жобасының болуына және оның орындалатын жұмысқа сәйкес келуіне көз жеткізуге міндетті;

- наряд-рұқсатты берушіден оны толтырған кезде бірлестіріліп жүргізіліп жатқан жұмыстардың болуы немесе болмауы туралы ақпараттың көрсетілуін, бар болғаны жағдайда қауіпсіздік шараларды солардың есебімен және әртүрлі бригадалар орындайтын жұмыстар аймақтарының нақты шектерін белгілеумен көрсетілуін талап етуге міндетті;

2) Жұмыстарды орындау алдында жұмыстарды өндіруші: міндетті;

- наряд-рұқсатта жазылған барлық қауіпсіздік шаралардың орындалуына көз жеткізуге

- жұмыстардың жауапты жетекшісімен қоса:

- бірлестіріліп жүргізіліп жатқан жұмыстардың болуын немесе болмауын, бар болғаны жағдайда - барлық қауіпсіздік шаралардың орындалуын тексеруге міндетті;

- жұмыстар жүргізілетін аймақта қауіптерге идентификациялауды және тәуекелдерге бағалауды жүргізуге міндетті;

3) Жұмыстарды орындау барысында жұмыстарды өндіруші жұмысқа жіберушіден немесе жұмыстардың жауапты жетекшісінен жұмыстарды орындаушылардың қауіпсіздігіне әсер ететін технологиялық үдерістердегі ауытқулардың пайда болуы туралы мән-жайды біліп тұруға міндетті. 
Otarov Yertay Zhalgasbayevich, doctor of medical Sciences, Karaganda regional branch of Republican research Institute for labor protection Ministry of Labor and Social Protection of the Population of the Republic of Kazakhstan»,

Karaganda city, Republic of Kazakhstan

E-mail: otarov_kgmu@mail.ru, ORCID ID: 0000-0001-5799-3451
Musakhanova Manshuk Serikovna, master of technical Sciences,

LLP "Kazakhmys Maker", Karaganda city, the Republic of Kazakhstan,

E-mail:

Manshuk.Musahanova@kazakhmys.kz

ORCID ID: 0000-0002-6370-8247

\title{
Issues of safety and labor protection of employees of contractors and proposals for their solution
}

\begin{abstract}
The article presents the safety measures of employees of contractors working on the territory of large industrial enterprises, and the prevention of accidents. Currently, many large companies hire contractors for the production of works, so the cases of high injuries of employees of contractors in recent years have re-energized the interest of many employers to improve the safety of these workers. Employees of Contracting companies are often injured on the territory of the customer, and the main cause of accidents is poor organization of work. Despite the widespread use of contract work, to date, has not formed a unified approach to how to solve this problem. In case of possibility to specify in the act of investigation of accident and The act of accident guilt of the third parties is obvious reduction of negative consequences for the enterprise in which the worker suffered.
\end{abstract}

Keywords: labor protection, safety, injury, accident, contractors.

Мақалаға сілтеме: Отаров Е. Ж., Мусаханова М. С. (2019), Мердігерлік ұйымдар жұмыскерлерінің еңбек қауіпсіздігі мен еңбектерін қорғау мәселелері және оларды шешу бойынша ұсыныстар. «Ғылымның өзекті мәселелері» - Халықаралық практикалық интернет- конференция материалдары / Materials of International Practical Internet Conference "Challenges of Science". ISBN 978-601-323-144-0. Басылым II, 2019. Бет: 128-131. https://doi.org/10.31643/2019.025

\section{Пайдаланылған әдебиеттер тізімі}

[1] Н. Симонова, С. Вихров, В. Иванов. Заказчик и подрядчик. Взаимодействие и контроль // «Охрана труда и социальное страхование», № 5, 2016.

[2] Руководство по системам управления охраной труда. MOT-СУОT 2001 ILO-OSH 2001.

[3] OHSAS 18001:2007 Системы менеджмента профессионального здоровья и безопасности труда.Требования. 